
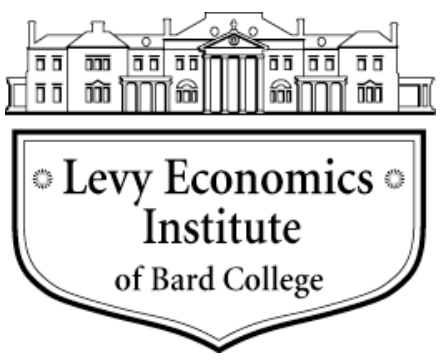

Working Paper No. 829

\title{
The Repeal of the Glass-Steagall Act and the Federal Reserve's Extraordinary Intervention during the Global Financial Crisis
}

by

\author{
Yeva Nersisyan*
}

Franklin and Marshall College

January 2015

*yeva.nersisyan@fandm.edu

The Levy Economics Institute Working Paper Collection presents research in progress by Levy Institute scholars and conference participants. The purpose of the series is to disseminate ideas to and elicit comments from academics and professionals.

Levy Economics Institute of Bard College, founded in 1986, is a nonprofit, nonpartisan, independently funded research organization devoted to public service. Through scholarship and economic research it generates viable, effective public policy responses to important economic problems that profoundly affect the quality of life in the United States and abroad.

\author{
Levy Economics Institute \\ P.O. Box 5000 \\ Annandale-on-Hudson, NY 12504-5000 \\ http://www.levyinstitute.org
}

Copyright (C Levy Economics Institute 2015 All rights reserved 


\begin{abstract}
Before the global financial crisis, the assistance of a lender of last resort was traditionally thought to be limited to commercial banks. During the crisis, however, the Federal Reserve created a number of facilities to support brokers and dealers, money market mutual funds, the commercial paper market, the mortgage-backed securities market, the triparty repo market, et cetera. In this paper, we argue that the elimination of specialized banking through the eventual repeal of the Glass-Steagall Act (GSA) has played an important role in the leakage of the public subsidy intended for commercial banks to nonbank financial institutions. In a specialized financial system, which the GSA had helped create, the use of the lender-of-last-resort safety net could be more comfortably limited to commercial banks.

However, the elimination of GSA restrictions on bank-permissible activities has contributed to the rise of a financial system where the lines between regulated and protected banks and the so-called shadow banking system have become blurred. The existence of the shadow banking universe, which is directly or indirectly guaranteed by banks, has made it practically impossible to confine the safety to the regulated banking system. In this context, reforming the lender-of-last-resort institution requires fundamental changes within the financial system itself.
\end{abstract}

Keywords: Banks; Central Banking; Deregulation; Federal Reserve; Financial Crises; GlassSteagall Act; Lender of Last Resort; Minsky; Regulation; Securitization; Shadow Banking

JEL Classifications: B50, E50, E58, G10, G18 


\section{INTRODUCTION}

One of the important features of the Fed's response to the financial crisis was the wide range of facilities that it created to prop up specific markets and institutions. While traditionally, the lender-of-last-resort support was thought to be limited to commercial banks, during the crisis this safety net was extended to a wide array of markets and institutions - brokers and dealers, money market mutual funds, the commercial paper market, the mortgage-backed securities market, the tri-party repo market, etc. The Fed expanded the circle of its counterparties to include almost every type of financial institution, and even individuals and foreign central banks. It also expanded the type of collateral it accepted (see Cheun et al., 2009). Indeed, the support granted to commercial banks proper constituted only a small part of the Fed's overall intervention.

The consensus is that the Fed's extraordinary intervention is warranted given the extraordinary nature of the crisis. If the crisis itself was a rare event, then the same is true about the Fed's actions. But since the financial system we have today closely resembles the one that failed in 2007, there is no reason to expect that a similar response won't be forthcoming next time there is a crisis. Therefore, we should attempt to understand why it has become difficult to contain the safety net within the regulated banking system as it had been done many times in the past. In this paper, we argue that the elimination of specialized banking through the eventual repeal of the Glass-Steagall Act (GSA) has played an important role in the leakage of the public subsidy intended for commercial banks to nonbank financial institutions.

In a specialized financial system, which Glass-Steagall had helped create, the use of the safety net could be more comfortably limited to commercial banks. Since a significant part of private liquidity creation occurred on the balance sheets of commercial banks, the provision of central bank liquidity to these institutions was sufficient to stall crises. Moreover, support in times of distress came at the cost of tight regulation and supervision of banks by the lender of last resort. The institutions that operated through access to capital markets, such as investment banks, had liquidity lines with large commercial banks, effectively making the latter their lenders of last resort (LOLR).

The elimination of compartmentalization in the financial system raised some issues for the use of the public safety net. In a system where various financial activities were to be combined under the roof of one organization, it was no longer clear which activities and which 
institutions would enjoy the public subsidy. As Gerald Corrigan $(1982,6)$ argued, the existence of the LOLR and deposit insurance presented important problems for eliminating the separation between commercial banks and other financial entities. The repeal would necessitate either getting rid of this safety net, or making it available to every institution that performed "banking functions." The proponents of the repeal charged back that the holding company structure would insulate the bank subsidiary from the losses of nonbank subsidiaries. Moreover, sections 23A and 23B of the Federal Reserve Act, which placed restrictions on the terms of transactions between banks and their affiliates, would provide an extra layer of protection (Benston 1990).

Clearly, the post-GSA financial system didn't pass the "insulation" test during the first major crisis it faced. The public subsidy generously leaked to nonbank institutions through two routes: indirectly, through inter-affiliate transfers, and directly, through the Fed's lending facilities created for different markets and institutions. ${ }^{1}$ While the transfer of the public subsidy within the holding company can be easily traced back to the elimination of specialized banking, the link between the repeal of the GSA and the more direct intervention of the Fed requires further elaboration. We argue that the elimination of GSA restrictions on bank-permissible activities has contributed to the rise of a financial system where the lines between regulated and protected banks and the so-called shadow banking system have become blurred. The existence of the shadow banking universe, which is directly or indirectly guaranteed by banks, has made it practically impossible to contain the safety net within the regulated banking system. Therefore, simply helping the banks and even allowing them to bail out their subsidiaries wouldn't have stalled the crisis. The markets in which these banks were actively involved had to be supported as well, necessitating the opening of discount window lending to nonbanks. Moreover, the proliferation of the shadow banking system itself can be traced to the breakdown of walls between banks and the rest of finance. Thus, the Fed's rush to support the shadow banks during the financial crisis must be understood in the context of the relationship of banks and the shadow banking system that has materialized in the post-GSA financial system.

As the financial system has not undergone major changes since the crisis, there is little doubt that the Fed's "extraordinary actions" will become the norm. In fact, Dodd-Frank has reaffirmed the ability of the Fed to lend to nonbank financial institutions in "unusual and exigent circumstances," provided the Fed gets the Treasury's approval. Some have welcomed the

\footnotetext{
${ }^{1}$ It is worth mentioning that most of the beneficiaries of the Fed's largesse were not previously under the Fed's direct regulatory purview.
} 
extension of central bank support to nonbank counterparties as an assumption of the Fed's proper role in the modern, market-based financial system (see Mehrling 2010; Mehrling et al. 2012; Buiter 2008). Others have been more critical of the expansion of the public safety net to the financial sector and the socialization of what should have been private losses. The critics of the open-ended central bank support have argued that central bank guarantees should have some upper limit (Moe 2012). Ultimately, the issue boils down to the desirability of the type of financial system that has emerged in the past two decades. If the current financial system is, in fact, a positive development that provides economic and social benefits, then we need to think of ways to support it to make it more stable. But if it's not, then we need to reform the financial system to prevent the misuse of the public safety net, rather than reforming the safety net to fit this new system. Ultimately, the boundaries of the safety net need to be clearly delineated and the beneficiaries should be tightly regulated and supervised.

The rest of the paper is organized as follows: Section 2 discusses the shadow banking system and demonstrates that the repeal of the GSA has acted as a catalyst in the emergence of this system. It also argues that the bank-shadow bank nexus has made the previously successful two-tiered lender of last resort system, where the central bank lends to commercial banks and the latter lend to nonbanks, unworkable. Section 3 examines how the crisis started as a run on the shadow banking system and the actions that the Fed took to support various participants of this system. In addition to the facilities that the Federal Reserve set up to lend to different financial institutions, it also frequently suspended the rules that govern inter-affiliate transactions, thus allowing for the public subsidy to leak to nonbank affiliates of commercial banks. While the various facilities have received much press, the more subtle transfer of the subsidy has gone largely unnoticed. Section 4 discusses some principles for reforming the lender of last resort system to prevent the open-ended, and in many ways, unconditional commitment of public funds to private financial institutions. Section 5 concludes.

\section{THE SHADOW BANKING SYSTEM}

Since the financial crisis, there has been an increased interest in studying the so-called shadow banking or market-based financial system that has emerged in the past two decades. Traditionally, commercial banks have been the main suppliers of liquidity to the economy. The creation of liquidity by commercial banks involves accepting the illiquid liabilities of both 
nonfinancial and financial entities in exchange for their own liquid liabilities. As banks have access to the LOLRs, they don't rely on financial markets for their ability to create liquidity. In the past two decades the so-called market-based institutions have become increasingly important in supplying liquidity. Some have called these institutions shadow banks due to their ability to perform banking functions, although outside of the regulatory purview, i.e., in the shadows (McCulley 2007). The shadow banking system includes a broad set of financial intermediaries that participate in the process of liquidity creation through their access to financial markets. This includes hedge funds, private equity funds, money market mutual funds, broker-dealers, conduits, Structured Investment Vehicles (SIVs) and other special-purpose, off-balance-sheet vehicles (SPVs), ${ }^{2}$ mortgage brokers, finance companies, etc. Pozsar et al. (2010, 2) define shadow banks as entities that perform "credit, maturity and liquidity transformation similar to traditional banks" but without public guarantees or access to the central bank as the LOLR.

Despite the existence of market-based institutions that create liquidity, such as investment banks, it wasn't until the widespread use of securitization that the shadow banking system exploded, overtaking the commercial banking sector in terms of asset size. "The shadow banking system is organized around securitization and wholesale funding" (Pozsar et al. 2013, 6). In case of securitization, "liquidity is created by the structure of the balance sheet of a separate institution, such as a trust or a special purpose entity (or vehicle)... [through which] higher-risk, longer-term assets are transformed into lower-risk, shorter-term assets, and thus, lower-liquidity assets into higher-liquidity assets.” (Kregel 2010,9) In the second quarter of 2007 , near the peak of the bubble, the assets of market-based institutions involved in securitization were 16 trillion (GSEs, GSE pools, ABS Issuers, broker dealers, finance companies), 1.2 times that of depository institutions (commercial banks, savings \& loans and credit unions) (Adrian and Shin 2009, 1). This trend of the rising importance of shadow banks was especially pronounced in the mortgage market, with market-based institutions holding two thirds of the $\$ 11$ trillion worth of home mortgages (ibid, 4).

The funding of shadow banking institutions came through secured and unsecured borrowing in the commercial paper and repo markets (Pozsar et al. 2013,6) and hence was short term. Institutional investors were the major suppliers of funds. For instance, securitization conduits that used asset-backed commercial paper for their funding depended to a large extent

\footnotetext{
${ }^{2}$ For a detailed discussion of the mechanics of the shadow banking system see Pozsar et al. (2008), Pozsar et al. (2010), and Pozsar et al. (2013)
} 
on money market funds. Money market funds, mutual funds, pension funds and other institutional investors were the counterparties of broker-dealers in repo transactions. Pozsar and Singh (2011) and Pozsar (2011) demonstrate that asset managers in general, including pension and mutual funds need short-term credit market instruments such as asset-backed commercial paper and repurchase agreements for liquidity management purposes and for achieving their desired yield. Thus, managed money in general created demand for the shorter-term liabilities issued by shadow banks. Importantly, the short-term positions had to be constantly refinanced, and thus the transformation of illiquid loans into highly liquid short-term credit market instruments required constant refinancing of positions (Kregel 2009, 10). Unlike commercial banks, the shadow banking system required an uninterrupted access to short-term funding markets for liquidity creation.

\subsection{The Repeal of the Glass-Steagall Act and the Rise of Shadow Banks}

Even though the shadow banking system is often described as a competitor of the traditional banking system, this characterization is not entirely accurate. The large financial conglomerates that have emerged since the gradual repeal of the Glass-Steagall Act have had one leg in each side of the system. Pozsar et al. (2013) label the portion of the shadow banking system in which bank holding companies are actively involved the "internal" shadow banking system, since by way of being within the holding company, it is still within the regulatory purview. "The "internal" shadow banking subsystem refers to the credit intermediation process of a global network of banks, finance companies, broker-dealers, and asset managers and their on- and offbalance-sheet activities - all under the umbrella of financial holding companies" (Pozsar et al. 2013 , 14). By combining commercial and investment banking activities under the same roof, financial holding companies have actively facilitated the rise of shadow banking (see Wilmarth 2009 and Nersisyan 2013). Through their nonbank subsidiaries, as well as their off-balance sheet activities, they have been enthusiastic participants in every step of the shadow liquidity creation process, from originating the loans destined for securitization, either directly or through their mortgage lender subsidiaries to securitizing these loans through off-balance sheet special purpose vehicles, as well as providing liquidity lines and credit enhancements to these securitization vehicles.

The first step in the securitization process is the origination of loans, which holding companies did through their bank subsidiaries (Pozsar 2013,9), as well as by buying up active 
nonbank mortgage lenders. The next steps are to "warehouse and accumulate loans in offbalance-sheet conduits that are managed by their broker-dealer subsidiaries..." and to "securitize loans through their broker-dealer subsidiaries by transferring them from the conduit into bankruptcy-remote special-purpose vehicles" (Pozsar et al. 2013 9-10). On average, from 2001 to 2007, the value of the loans securitized and sold (with servicing or other recourse retained) collectively by today's largest four holding companies_-JPMorgan Chase, Bank of America, Citigroup and Wells Fargo - amounted to about 42 percent of the value of their net loans and leases. The comparable number for 1-4 family residential loans was more than 85 percent. By contrast, assets securitized and sold by smaller banks (with assets from $\$ 1$ to $\$ 10$ billion) amounted to about 6 percent of the value of their net loans and leases. The comparable number for banks with assets greater than $\$ 10$ billion, excluding today's top four was only around 19 percent. $^{3}$

Originating loans is certainly a traditional commercial banking activity, which banks could do even under the GSA. However, under the GSA limitations, the bank holding company couldn't own a broker-dealer subsidiary, and would, therefore, need to securitize the loans through independent broker-dealers. In this case, the incentive to do diligent credit analysis before granting a loan would arguably be higher. If the independent broker-dealers were taking the risks of being stuck with bad loans, they would have a greater incentive to not buy bad quality loans. But if the entity that was buying and selling the loans were the same, as was the case with the holding companies, the evaluation of the quality of assets could be compromised. Arguably, they would still have some incentive to perform diligent underwriting, as the whole conglomerate could get stuck with the loans/securities if they couldn't sell them. However, as they derived their profits from origination fees, this could "compensate" for the risk they were taking and thus change the incentive structure.

At the peak of the bubble in 2006, the largest US financial holding companies (FHC), such as Washington Mutual, Wells Fargo, JPMorgan Chase, Citigroup and Bank of America, were among the 15 largest issuers of asset-backed and mortgage-backed securities worldwide. ${ }^{4}$ The large FHCs were also the biggest bookrunners, i.e., the distributors of the securitized products to institutional investors. In 2008, for instance, the market share of the top 10 bookrunners was 90 percent (Nersisyan 2013).

\footnotetext{
${ }^{3}$ Source: FDIC Statistics on Depository Institutions and author's calculations.

${ }^{4}$ See abalert.com for detailed information on banks' securitization activities.
} 
The large FHCs also used their depository institution arms to facilitate their acquisitions of nonbank institutions that were active participants in the shadow banking system. For instance, in 2000 Citigroup acquired one of the largest subprime lenders, Associates First Capital Corporation, and was allowed by the Federal Reserve Board to transfer " $\$ 46.7$ billion in AFCC's commercial finance, credit card, and international consumer finance assets [including $\$ 2.4$ billion of low-quality assets] to its bank subsidiaries..." (Omarova 2011, 1708). Citigroup got a few other exemptions from limits on inter-affiliate transactions, and consequently, transferred a sizable amount of subprime mortgage assets to its bank subsidiary. This type of transaction allowed Citigroup, as well as other FHCs to take advantage of their access to deposit insurance and the LOLR to facilitate their securitization activities (Omarova 2011, 1711-1713).

Perhaps the most important way in which traditional banks supported the shadow banking system was through the provision of liquidity lines and credit guarantees to the entities involved in the shadow liquidity creation process. ${ }^{5}$ Despite the fact that financial and nonfinancial entities have various sources of credit, commercial banks still represent an important source of liquidity for the economic system as a whole. Without credit supplied by banks, whether on a regular basis or through standby credit facilities, financial markets and nonbank financial institutions won't be able to function properly (Corrigan 1982, 4). The extreme maturity mismatch of shadow banking entities meant that positions needed to be constantly refinanced, which required the smooth operation of the short-term funding markets. Any minor financing difficulty could lead to a forced liquidation of positions leading to a fire sale of assets. The life span of the shadow banking system was thus limited to the willingness of institutional investors to invest in short-term credit market instruments. To prevent such an emergency liquidation, "Any prudent unit engaging in speculative finance will have alternative financing facilities available, [a lender of last resort] including some backup financing in case some primary channel either becomes too expensive or is no longer available” (Minsky 2008, 48). Even though the shadow banking system did not enjoy an official access to the Fed's discount window, many of the off-balance sheet vehicles had explicit or implicit access to liquidity lines from commercial banks. By acting as "lenders to other subsidiaries and off-balance-sheet

\footnotetext{
${ }^{5}$ Liquidity support is different from credit enhancements. Liquidity lines protect against rollover risk, while credit enhancements protect against default risk. Credit enhancements usually amount to 8-10 percent of the issue, while liquidity lines support the totality of the issue, excluding the value of defaulted collateral.
} 
vehicles involved in the warehousing and processing of loans, as well as the distribution and funding of structured credit securities" commercial bank affiliates of FHCs further supported the shadow banking system (Pozsar et al. 2013, 10).

The asset-backed commercial paper market, an important source of funding for shadow banks, wouldn't have been viable without the liquidity lines provided by commercial banks. Additionally, many of the largest mortgage lenders also got their regular and emergency funding from the largest financial institutions, including the largest universal banks (Wilmarth 2009, 1019-1020). But even "the best managed and capitalized broker/dealers" rely on bank lines of credit for their normal daily operations (Corrigan 1982, 4). For instance, when an underwriter of a guaranteed securities issue is unable to sell a portion of the issue, it needs to find another way to exchange the issuer's liability for currency or bank deposits. An unsold issue may necessitate that the bank "accept" the securities as collateral and issue a demand deposit against them. The regular funding of inventories of broker-dealers also requires access to commercial bank liabilities (Kregel 2012, 6). The tri-party repo market, ${ }^{6}$ where broker-dealers fund a large share of their activities, benefited from the support of the two clearing banks-JPMorgan Chase and the Bank of New York Melon. The role of the clearing banks was to provide intraday credit as the positions were unwound every day granting lenders access to their funds and borrowers access to their collateral. To emphasize the importance of repos for broker-dealers, at the peak of the boom in 2007, 38 percent of their funding came through these instruments (Adrian et al. 2009, 2).

The granting of liquidity lines is a traditional banking activity, which could have been conducted even under the Glass-Steagall limitations. So, one may argue that the repeal of the Act did not play an important role in the ability of commercial banks to support the shadow banking system. But here again the question of incentives becomes important. When a bank grants a liquidity line to an unaffiliated entity, it is accepting the rollover risk for a small fee. Therefore, it has an incentive to conduct diligent credit analysis before determining whether to grant such a line. The incentives change when the entity getting the liquidity line is an affiliate or an off-balance sheet entity. In this case, the bank has an incentive to grant a competitive advantage to its subsidiary, and therefore it may compromise its credit standards. Moreover, in

\footnotetext{
${ }^{6}$ A tri-party repo transaction involves three entities: the borrower, usually a broker-dealer; a lender, usually institutional investors; and a clearing bank. The clearing bank takes the collateral, determines the haircut and transfers the payments to the appropriate entities when the transactions are entered into and when they are unwound.
} 
this scenario it is not simply getting a fee for providing the line, but the holding company, which it belongs to, gets to pocket the profits from the particular activity that is getting the liquidity support.

In sum, nonbank financial firms' ability to create liquidity depends on their ability "to borrow in order to hold" their assets, which is based on their ability to make these assets "accepted" by deposit-creating banks. Ultimately, liquidity created by shadow banks relies on liquidity created by traditional banks — on the willingness of banks to "accept" their liabilities in exchange for their own. Hence, all liquidity, even that created through the capital markets is "ultimately dependent on the liquidity created by the banks" (Kregel 2012, 7), since banks are the only institutions that issue the means of payment. Placing commercial banks with the ability to create true liquidity under the same roof with entities that require access to that liquidity for their own activities was a recipe for disaster.

\subsection{The Breakdown of the Two-tiered Lender of Last Resort System}

Prior to the elimination of specialized banking the LOLR institution in the US was structured as a two-tiered system. The Fed acted as the LOLR to commercial banks, while the latter provided emergency lending to nonbank entities, both financial and nonfinancial. Even though bank credit lines are used in normal times, they become particularly important during crises and panics. As the only entities that are able to create deposits when they lend, banks are in a position to supply liquidity when others won't or can't (Corrigan 1982). This system performed well during the financial disturbances of the 70s and 80s, as both financial and non-financial institutions that needed emergency lending were able to use the banking system as a temporary solution, while looking for longer-term solutions to their problems. The ability to rely on banks even for a temporary solution of liquidity issues was important in containing these shocks within particular institutions or markets (Corrigan 1982, 4).

But with universal banking this system broke down for at least two reasons. First, with banks now competing with nonbank financial institutions, they could refuse to grant credit to their competitors, even if the latter were creditworthy. If the bank and the institution requesting credit were competitors in some other line of business, the bank could be tempted to let the competitor fail. Second, the largest banks that are the most important providers of lines of credit belong to financial holding companies. Their engagement in the same type of activities as nonbank institutions may make them unable to serve as LOLRs. For instance, if a broker-dealer 
is unable to fund its inventory of mortgage-backed securities in the market, it may have to turn to a bank for a bridge loan. However, a universal bank may itself have a broker-dealer subsidiary with significant positions in the asset class that is difficult to fund in the market. If this institution is facing the same challenges as others that want to borrow from it, it may not be willing or able to lend to them. The bank itself may be in no position to act as an LOLR as it needs to turn to the Fed on its own account. Moreover, banks may also have an incentive to support their own affiliates at the expense of other institutions. Corrigan $(1982,5)$ rightly argues that in crises situations, banks' ability to be an impartial judge of other institutions' creditworthiness is especially important, as it is in times like that when "potential for compromise in the impartiality of the credit decision making process is greatest and the potential for asset quality deterioration is the largest." During the financial crisis, banks were unable to support nonbank entities that needed liquidity, creating the need for direct lending by the Federal Reserve.

\section{THE RUN ON SHADOW BANKS AND THE FED'S INTERVENTION}

As early as 1993, Boyd and Gertler recognized that a "withdrawal of money market instruments," rather than a traditional run by depositors, had emerged as the source of instability in banking. They argued that the stability of the system was "tied critically to the judgments of lenders in the money market" (Boyd and Gertler 1993, 328). Similarly, Minsky $(1994,15)$ argued that a "run from these funds,", i.e., institutional funds, in the form of redemptions by investors would necessarily force asset liquidation and cause an asset price deflation. These insights were prophetic as the global financial crisis was triggered by a run on the shadow banking system. In August of 2007, after the French bank BNP Paribas suspended withdrawals from three funds that had invested in asset-backed commercial paper (ABCP), the ABCPfederal funds spreads shot up. As soon as investors became concerned about the state of the housing market, short-term funding markets dried up, cutting short the life span of market-based institutions. The amount of outstanding asset-backed commercial paper declined by about $\$ 411$ billion from 2007 to $2008 .{ }^{8}$ This was the beginning of the freezing of short-term funding

\footnotetext{
${ }^{7}$ Such a run seemed to have occurred in October of 1987 when block traders withdrew from the market (Minsky 1988, 3).

${ }^{8}$ Data from the US Flow of Funds Accounts
} 
markets. The repo market faced a run similar to the commercial paper market. The repo haircut index ${ }^{9}$ skyrocketed from "zero in early 2007 to nearly 50\% at the peak of the crisis in late 2008 " (Gorton and Metrick 2012, 428). Mortgage-backed securities, as well as other less liquid collateral such as asset-backed securities and corporate equities had come to be increasingly used as collateral for repo transactions in the run up to the crisis. Less liquid collateral constituted on average about 45 percent of total collateral in 2005, but increased steadily to more than 50 percent by 2007, and even reached 60 percent early in 2009 (Adrian et al. 2009, 4, chart 3). Another important trend was the move away from term-repo to overnight repo funding. Between 1998 and 2004, on average, only 50 percent of repo funding was overnight. By 2008 that number had reached 75 percent. At the same time, the size of the repo market had increased from $\$ 450$ billion in 1994 to $\$ 3$ trillion in 2008, representing a significant increase in short-term funding in the financial system (Adrian et al. 2009, 3). The increase in haircuts applied to less liquid collateral basically meant the freezing of the tri-party repo market. Combined with the short-term nature of repo transactions, this meant that without some support from the Fed, the tri-party repo market was basically useless as a funding source for broker-dealers that needed to finance their inventories.

Once short-term funding markets dried up, shadow banks had no LOLR to turn to. Instead, lines of credit at commercial banks served as substitutes. But as Minsky (2008) recognized long ago, the ultimate fall-back institution for the system as a whole is the central bank, which puts a floor under asset prices by making the fire sale of assets unnecessary. Indeed, the collapse of asset prices and financial markets didn't stop until the Fed intervened. On March 16, 2008, the Fed created the Primary Dealer Credit Facility that "functioned as an overnight loan facility for primary dealers, similar to the way the Federal Reserve's discount window provides a backup source of funding to depository institutions" (Board of Governors of the Federal Reserve System). The facility accepted a wide range of collateral from Treasury securities to mortgage-backed securities and non-investment grade securities and equities (Adrian et al. 2009, 4-6). It was one of the most frequently used facilities with loan originations of about $\$ 9$ trillion or 30 percent of the Fed's overall intervention (Felkerson 2011). The Term Securities Lending Facility (TSLF), also geared at broker-dealers, was created just a few days earlier. Instead of lending funds, the TSLF lent securities to broker-dealers, and as such "was a

\footnotetext{
${ }^{9}$ The index is the weighted average of the haircuts on nine privately issued assets from corporate securities to CDOs (see Gorton and Metrick 2012, Table 2, Panel D for the assets included in the index).
} 
means to improve the average quality of broker-dealers' securities warehouses by swapping ABS for Treasury securities" (Pozsar et al. 2013, 12).

After the collapse of Lehman Brothers, the Reserve Primary Fund (a money market fund) "broke the buck" due to its exposure to Lehman's commercial paper, triggering a run on money market mutual funds. Since the latter were important investors in the commercial paper market (asset-backed and unsecured), the run on money market funds directly affected the commercial paper market. It is important to note that while nonfinancial firms use the commercial paper market to raise working capital, financial firms such as finance companies, asset-backed securities issuers, banks and holding companies, as well as foreign financial companies issue most of the commercial paper. As of August 2007, 90 percent of the $\$ 2.2$ trillion market constituted asset-backed commercial paper (52 percent) and financial commercial paper (38 percent) issued by banks, finance companies and foreign financial institutions (Adrian et al. 2010, 5). Even after the crisis, out of the total commercial paper outstanding at the end of 2012, nonfinancial corporate business had issued only 13 percent, while foreign financial business had issued 34 percent and US domestic financial institutions, the remaining 47 percent. The Fed established the Commercial Paper Funding Facility (CPFF) to act as an LOLR for the commercial paper market and to stall the run on the issuers. The Fed effectively created a special purpose vehicle that bought highly rated commercial paper from non-financial and financial issuers and used those assets as collateral for borrowing from the New York Federal reserve bank (Adrian et al. 2010, 14). As asset-backed security issuers, that issued ABCP among other liabilities were an important part of the shadow banking system, this was essentially a discount window for the shadow banking system.

In addition to the CPFF, the Fed also created the Asset-Backed Commercial Paper Money Market Mutual Fund Liquidity Facility (AMLF) and the Money Market Investor Funding Facility ${ }^{10}$ to support short-term credit markets (Adrian et al. 2010, 23). Through the AMLF, the Fed granted nonrecourse loans to US depository institutions to purchase eligible ABCP from money market mutual funds. The stated purpose of the AMLF was to "help MMMFs that held asset-backed commercial paper (ABCP) meet investors' demands for redemptions, and to foster liquidity in the ABCP market and money markets more generally" (Board of Governors of the Federal Reserve System). The total loan originations through the

\footnotetext{
${ }^{10}$ Even though no loans were made through this facility, the design and purpose were similar to the AMLF, but with broader eligibility for borrowers.
} 
CPFF and AMLF were about $\$ 1$ trillion, or a little over 3 percent of the Fed's total intervention (Felkerson 2011). To the extent that the AMLF helped money market mutual funds stuck with illiquid assets to meet share redemptions, it was similar to an LOLR lending to a commercial bank facing temporary liquidity issues. However, considering the questionable quality of a lot of the asset-backed paper issued during the boom, it is not clear whether the Fed provided liquidity support, or simply bailed out institutions stuck with assets of questionable quality.

The run on shadow banking was in part a run on the unprotected subsidiaries and offbalance sheet vehicles of the largest financial conglomerates. As explained above, in the modern financial system the links between banks and nonbanks ran far and deep. Many of the universal banks had large broker-dealer subsidiaries that were active in the securitization process. The large holding companies also sponsored a sizable portion of the asset-backed commercial paper conduits. As sponsors of the conduits, they provided liquidity and credit guarantees, which, if triggered, would leave them on the hook for losses. Had the Fed limited its lending to commercial banks only, it might not have been able to prevent a system-wide debt deflation. The largest universal banks would probably still fail due to their connections to the shadow banking system. The Fed clearly realized that the only way to save and preserve the financial system was through broad intervention encompassing the markets where these institutions were active. The rise of shadow banking that was tightly intertwined with regulated banks had not only changed the face of the financial system, but also altered the efficacy of traditional LOLR interventions.

The above discussion should not be taken as a justification for the Fed's actions. It is not clear whether saving the financial system in its former form was the desirable public policy objective. The market-based system was praised for being more efficient than the bank-based system. The financial crisis demonstrated that this system couldn't survive without public guarantees. Considering the unstable nature of shadow liquidity creation, by letting certain markets and institutions fail, the Fed may have contributed to a new and healthier financial structure in the longer term.

\subsection{Indirect Transfer of Subsidies}

While the direct provision of discount lending to nonbank entities has received a great deal of attention, a more subtle transfer of the public subsidy to unprotected institutions has gone largely unnoticed. In an excellent paper, Saule T. Omarova (2011) details the Federal Reserve 
Board's practice of granting exemptions to financial conglomerates from restrictions on interaffiliate transactions during and before the crisis, and thus allowing for the public subsidy to leak to nonbank entities. In the discussions leading up to the repeal of the GSA, critics argued that in a universal banking system an FHC's bank subsidiary could channel funds obtained from the central to the nonbank subsidiaries. It could also buy assets that the subsidiary couldn't sell in the market, or pay a price not justified by market conditions, thus taking the risks of the subsidiary into the bank's books. Those who supported the repeal of the law argued that housing nonbank activities in separate subsidiaries of the holding company would help insulate the bank subsidiary from nonbank subsidiaries. Furthermore, sections 23A and 23B of the Federal Reserve Act would safeguard against the transfer of funds and subsidies between subsidiaries (Benston 1990, 25). Section 23A states that "a member bank and its subsidiaries may not purchase a low-quality asset from an affiliate unless the bank or such subsidiary, pursuant to an independent credit evaluation, committed itself to purchase such asset prior to the time such asset was acquired by the affiliate." Additionally, any extension of credit from the bank to the affiliate must be collateralized and "[a] low-quality asset shall not be acceptable as collateral for a loan or extension of credit to, or guarantee, acceptance, or letter of credit issued on behalf of, an affiliate, or credit exposure to an affiliate resulting from a securities borrowing or lending transaction, or derivative transaction.” Section 23B places further restrictions on transactions between banks and their nonbank affiliates by requiring that they be "on terms and under circumstances, including credit standards, that are substantially the same, or at least as favorable to such bank or its subsidiary, as those prevailing at the time for comparable transactions with or involving other nonaffiliated companies..."

It was clear to others that simply housing diverse activities in different subsidiaries wouldn't insulate them from each other. Corrigan $(1982,5)$ argued that especially in times of crisis and panic, such insulation wouldn't be feasible. And arguably, it is in times of crisis that barriers become especially important. As Shull $(2002,56)$ puts it, the barriers "work reasonably well in good times, but are prone to deteriorate in bad times, and are unlikely to work at all in exigent circumstances."

While the transfer of the subsidy seemed like a remote possibility when the GSA was repealed, it became very real in the midst of the crisis. As Omarova (2011) discusses, the Board continuously granted exemptions, which went against what Section 23A was supposed to accomplish_-protect regulated banks from losses of their nonbank affiliates, as well as prevent 
the transfer of the public subsidy to the latter. As the Fed set up direct funding facilities for nonbank entities, it also allowed banks to engage in prohibited transactions with their nonbank affiliates. For instance, the Board granted a broad (rather than institution specific) exemption to depository institutions, allowing them to buy ABCP from affiliated money market funds when it set up the AMLF. It argued that since the loans from the Fed were non-recourse loans, the banks would not be on the hook for losses, even if the ABCP lost value. What it failed to note, however, is that one of the functions of Section 23A was to protect the safety net from being used for non-bank entities, and that's exactly how it was used (Omarova 2011, 1736-1737). With the establishment of the Primary Dealer Credit Facility, the Board granted an exemption allowing banks to fund those activities of their affiliates that would normally be funded through the tri-party repo market (Omarova 2011, 1740). As it created the Term Auction Facility (TAF), it also made it easier for non-bank affiliates of universal banks to engage in transactions exempt from Section $23 \mathrm{~A}$ regulations with their bank affiliates. These exemptions were set to expire together with the TAF. It argued that the purpose of these exemptions was to get the needed liquidity to non-affiliated nonbank entities, but certainly it also helped banks own affiliates (Omarova 2011, 1728-1729).

\section{POLICY GOING FORWARD}

Even though Dodd-Frank took on Section 13(3), demonstrating a need to reform the Fed's extraordinary powers, it did not curtail them in any meaningful way. Quite the contrary, it merely reaffirmed the Fed's ability to establish lending facilities to support the financial sector in a crisis in a more or less open-ended manner. Dodd-Frank does require that such facilities have broad-based eligibility, thus preventing an AIG-style bailout (Shull 2012, 8). But it doesn't prevent the Fed from supporting the insurance industry as a whole, for instance. It also requires that the Fed obtain the Treasury's approval before establishing such facilities and submit reports to Congress (ibid). It is doubtful that this will act as a deterrent in a panic. During the financial crisis, we had a Fed Chairman appointed by a Republican president and a Democratic administration, who nevertheless acted together to save the financial system.

As Minsky long recognized, capitalism is a financial system, and financial disturbances and crises are woven into its fabric. If we start our analysis from this perspective, there are obvious benefits to having a safety net for certain financial institutions. Guaranteeing that the 
value of the liabilities of some institutions, such as banks, will not fall below par is one of the important responsibilities of the government with respect to the performance of the economy ${ }^{11}$ (Minsky 1992, 11). By guaranteeing the liabilities of particular institutions through deposit insurance and the LOLR, the government turns purely private liabilities, whose nominal value can fluctuate, into publicly protected liabilities with a fixed nominal value. Such a guarantee ensures that in conditions of increased uncertainty, when there is a tendency to substitute private liquidity with public liquidity, there is one type of privately created financial liability that is as good as the liability of the government. Hence, private liquidity creation need not cease in financial panics, and credit can continue to flow to both financial and nonfinancial firms. A public guarantee prevents the mass exodus out of private liquidity in times of crisis and creates some modicum of stability in an unstable economy.

The important question is whose liabilities the government should guarantee, and consequently who should get access to the LOLR. Should a lender of last resort facility be open to every type of financial institution, or should we attempt to create clear boundaries for the safety net? Some have welcomed the Fed's broader powers as an assumption of its proper role in the modern, market-based financial system. Mehrling (2010) and Mehrling et al. (2012) have argued in favor of the Fed acting as a backstop for the dealer system, i.e., a "dealer of last resort." In a similar vein, Buiter $(2008,32)$ supports a permanent role for the Fed as a "market maker of last resort," which it should fulfill through outright purchases and by accepting "as collateral in repos and similar secured transactions, systemically important financial instruments that have become illiquid." Such a change of practice would in turn necessitate "extending the range of eligible counterparties to include all institutions deemed systemically important (too large or too interconnected to fail)." Others have been more skeptical of the desirability of a blanket lender of last resort policy. The reasons range from the undemocratic nature of this subsidy to the financial sector (Improving Governance of the Government Safety Net in a Financial Crisis 2012) to the potential loss of independence of the central bank if it dives deeper into the territory of what should be fiscal policy (Goodfriend 2011). Moe $(2012,4)$ believes that "[e]ven when the central bank has the ability to create abundant official liquidity, there should be some limits to its support for the financial sector." He argues for a two-part policy for determining an "upper limit" for central bank intervention during crisis, in conjunction with

\footnotetext{
${ }^{11}$ Minsky (1991) argued that allowing the value of depository institution liabilities to fall below par was an important ingredient in the debt deflation during the Great Depression.
} 
trying to minimize the need for it (ibid). One can add that, especially since the central bank does not face any limits on its ability to create liquidity, its hands should be somehow tied to prevent the misuse of this important power.

More importantly, the question of whether the unconventional intervention of the Fed should become a permanent feature of our economy goes back to the question of whether the modern financial system that has emerged as a result of deregulation is a desirable development. Those who favor making the Fed's powers permanent must either implicitly assume that it is, or that even if it's not, reforming it is not feasible. Pozsar $(2011,22)$ is explicit when he says the following:

"... if the aim is to involve institutional cash pools in credit intermediation to the private sector, recognizing the fact that institutional cash pools prefer to invest cash at a distance from banks and in secured, that is non-M2 types of instruments, implies the broadening of lender of last resort access to non-bank intermediaries that issue such instruments, such as broker-dealers (in the case of repo) and various types of maturity transformation vehicles that issued instruments such as asset-backed commercial paper, et cetera."

In other words, if we want institutional investors to be a part of the "credit intermediation" process, then the instruments that these investors buy should be granted some form of public protection to prevent runs on the institutions that issue them. The social value of such an arrangement is not entirely apparent, however. For example, why does it make sense for a pension fund to own a piece of someone else's mortgage? And even though the market-based system was supposed to be more efficient in providing liquidity to the real economy, it is clear that shadow banking has been able to proliferate partly due to its implicit and free access to the central bank. The financial crisis provides some evidence that it has failed the test of the "marketplace," and was unable to survive without massive government guarantees. The burden of demonstrating that market-based finance is a better system compared to the one where liquidity creation occurred on the balance sheets of commercial banks rests with the supporters of this system.

Reestablishing certain limits on the LOLR activity of the Fed, on the other hand, requires recreating some of the compartmentalization that existed in the financial system prior to the repeal of the GSA. A useful principle to start from is that no private entity should enjoy a government subsidy unless it serves a public purpose. For instance, if we claim that only commercial banks should get access to the LOLR, then we need to explain what socially useful 
function they perform. This requires an understanding of what banks are and how they are different from nonbank financial institutions.

It may be argued that despite the emergence of different types of financial institutions that perform bank-like functions in the post-WWII period, banks are still special. Corrigan $(1982,2)$ singles out banks' ability to issue "transaction accounts" as one of the important characteristics that makes them special.

Banks "incur liabilities payable on demand at par and [that] are readily transferable by the owner to third parties. The owner of a transaction account can demand and receive currency in the face amount deposited in the account; write a check in the full amount of the account; or perhaps most importantly the owner of the account can transfer the full amount of the account to a third party almost instantaneously by wire transfer" (ibid).

The only institutions in the financial system that come close to issuing transaction accounts are money market mutual funds. Before the crisis money market fund shares were perceived to be as good as bank deposits because they offered check-writing privileges (with certain limitations), and most importantly "guaranteed" a net asset value (NAV) of \$1. In other words, a dollar deposited into a money market fund was "guaranteed" a redemption value of at least one dollar. However, as Corrigan $(1982,3)$ rightly observes,

"instruments which appear to have bank transaction account characteristics take on those characteristics in part because the acquisition or disposition of such assets involves, at some point, the use of a transaction account at a bank. However, technology makes it possible to manage these financial assets in a way in which their ultimate dependence on a bank account is not apparent to the individual holder of the asset."

For instance, the acquisition of money market fund shares usually involves a transfer of bank deposits to a money market fund at some point. Banks, on the other hand, may issue transaction accounts in two ways. First, they may accept deposits of government money or checks drawn on other banks, which is similar to what money market funds do. Secondly, and most importantly, they can issue transaction accounts when granting loans, basically creating money out of thin air (Kregel 2013).

However, stating that banks are special because they issue transaction accounts payable on demand and at par, and should, therefore, have access to the lender of last resort is a circular argument. It is true that banks are the only entities that can issue the means of payment, but that doesn't necessarily stem from anything that's special about banks, but is rather a monopoly that the government grants to banks when it guarantees their liabilities. The latter involves deposit 
insurance, but most importantly the access to the central bank, which is ultimately the currency monopolist in the economy. Therefore, the issuance of transaction accounts cannot really define banks and serve as a criterion for erecting lender of last resort boundaries.

What is special about banks is not the fact they issue the means of payment, and hence, create liquidity, but how they do that. Banks create liquidity by "accepting" the liabilities of other economic agents and substituting their own liabilities for the accepted liabilities. According to Minsky "The fundamental banking activity is accepting, that is, guaranteeing that some party is creditworthy. A bank, by accepting a debt instrument, agrees to make specified payments if the debtor will not or cannot. ... A bank loan is equivalent to a bank's buying a note that it has accepted." $(2008,256)$

If performed properly, banks' "acceptance" of other sectors' liabilities allows creditworthy customers to get funding to support the continuous use of capital equipment or to finance consumption, which still indirectly finances investment. By accepting the less liquid liabilities of households and firms and substituting their own liabilities for these, banks create liquidity which supports the capital development of the economy, broadly defined (Wray 2010). Thus, the "acceptance" function of commercial banks has a socially useful role. The proper performance of the acceptance function, however, requires that the risks be held on the bank's balance sheet. As the bank is taking the risk of failure of the borrower, it is a partner of the borrower, rather than simply a lender, and therefore has an incentive in the borrower's success (Minsky 2008, 260). Even though money market mutual funds, investment banks and a whole host of markets and institutions participate in private liquidity creation as described in Section 2, none of this involves the acceptance of clients' liabilities based on credit analysis.

As a practical policy matter, we could use the principle that only depository institutions with publicly guaranteed liabilities should have access to the LOLR. Furthermore, all other institutions should be prohibited from offering deposit-like instruments with implied guaranteed nominal value. Using government insurance as a precondition for LOLR support will certainly limit the type of institutions that can have access to the Fed. It is true, that during the crisis, the Treasury decided to guarantee par redemption of money market fund liabilities. ${ }^{12}$ Hence, even

\footnotetext{
12 This option no longer seems to be on the table as the Emergency Economic Stabilization Act of 2008 now explicitly prohibits the Secretary of Treasury from "from using the Exchange Stabilization Fund for the establishment of any future guaranty programs for the United States money market mutual fund industry." (Emergency Economic Stabilization Act of 2008, Public Law 110-343, 122 Stat. $3765 \S 131$ )
} 
this principle could be violated in times of peril. But arguably, this is harder to do than simply grant access to the LOLR facility to every entity in the economy.

The above-mentioned recommendations do not solve all the problems that the existence of universal banks poses for the safety net. Even if the safety net were restricted to depository institutions, universal banks would still enjoy access to it, and could transfer the subsidy to their nonbank affiliates. To avoid this, rules guiding transactions between banks and their affiliates need to be strengthened and most importantly adhered to. Dodd-Frank attempts to strengthen the walls separating banks and their nonbank subsidiaries by broadening the transactions covered under Section 23A and tightening the requirements for granting exceptions. Derivatives and securities lending and borrowing are now considered "covered transactions" under Section 23A. Collateral requirements for transactions with affiliates have also been strengthened. Even though the Federal Reserve Board still retains the ability to grant exemptions, this authority is now shared with the OCC and FDIC. Importantly, the FDIC has the power to veto the granting of exemptions if doing so "presents an unacceptable risk to the federal deposit insurance fund" (Omarova 2011, 364).

But as Omarova (2011) points out, Dodd-Frank does not alter "the fundamental dynamics of the regulatory decision making in times of crisis" (1762). Rules may have been strengthened, but the recent experience shows that rules are easily bent in the name of serving the public interest when the survival of the system is at stake. And more importantly, as has been explained in Section 2, the ability to implicitly take advantage of the safety net by affiliating with a commercial bank has acted as a major catalyst in the proliferation of the shadow banking system. Strengthening the rules that govern inter-affiliate transactions could potentially stall this process from moving forward (Omarova 2011, 1765). Clearly setting the expectations of financial firms about where the lender of last resort line is drawn may prevent the further rise of the market-based system that is implicitly sponsored by banks and hence, the government.

\section{CONCLUSION}

The repeal of the Glass-Steagall Act has created a financial system where banks and nonbanks are increasingly intertwined. This interconnectedness has altered the efficacy of traditional lender-of-last-resort activities, making it impossible to support one without supporting the other. 
It necessitated the unprecedented intervention of the Federal Reserve during the crisis, which involved opening the discount window to a wide range of nonbank entities. It is not clear, however, whether the nonbank entities that got access to the Fed in the midst of the crisis serve a social function. Therefore, whether this should be the model for the LOLR institution going forward is up for debate.

Clearly, the purported benefits of the market-based financial system have not materialized. In fact, it was only able to survive thanks to significant support from the Federal Reserve. It is necessary to rethink whether it's the financial system, rather than the LOLR institution that needs to be reformed. Going back to a system where most of the liquidity creation occurs on the balance sheets of banks may be the right solution. Even though DoddFrank did not compartmentalize the financial system, it is still possible to recreate boundaries within it by establishing boundaries for the public safety net. One useful principle for recreating limits on the use of the safety net is that only entities that serve the public purpose may have access to it. Moreover, such institutions need to be tightly regulated and supervised by the lender of last resort itself. 


\section{References}

Adrian, T., K. Kimbrough, and D. Marchioni. 2010. "The Federal Reserve's Commercial Paper Funding Facility,” Federal Reserve Bank of New York Staff Report No. 423. January.

Adrian, T. and H.S. Shin. 2009. "The Shadow Banking System: Implications for Financial Regulation," Federal Reserve Bank of New York Staff Report No. 382. July.

Adrian, T., C.R. Burke, and J.J. McAndrews. 2009. “The Federal Reserve's Primary Dealer Credit Facility," Federal Reserve Bank of New York Current Issues in Economics and Finance, 15, 4.

Benston, G.J. 1990. The Separation of Commercial and Investment Banking: The Glass-Steagall Act Revisited and Reconsidered. New York: Oxford University Press.

Buiter, W.H. 2008. Central Banks and Financial Crises. Discussion paper, 619. Financial Markets Group, London School of Economics and Political Science, London, UK.

Boyd, John H., and M. Gertler. 1993. "U.S. Commercial Banking: Trends, Cycles and Policy," NBER Macroeconomics Annual, Volume 8, Olivier Blanchard and Stanley Fischer (ed.).

Cheun, S., I. von Köppen-Mertes, and B. Weller. 2009. "The Collateral Frameworks of the Eurosystem, the Federal Reserve System and the Bank of England and the Financial Market Turmoil," ECB Occasional Paper No. 207. Frankfurt, Germany: European Central Bank.

Corrigan, E.G. 1982. “Are Banks Special?” Annual Report Essay, Federal Reserve Bank of Minneapolis.

Felkerson, J.A. 2011. "29,000,000,000: A Detailed Look at the Fed's Crisis Response by Funding Facility and Recipient," Levy Economics Institute of Bard College, Public Policy Brief No 123.

Board of Governors of the Federal Reserve System. "Primary Dealer Credit Facility," News and Events: Regulatory Reform.

Goodfriend, M. 2011. "Central Banking in the Credit Turmoil: An Assesment of Federal Reserve Practice,” April. Journal of Monetary Economics. Vol. 58, Issue 1: 1-12.

Gorton, G. and A. Metrick. 2012. "Securitized Banking and the Run on Repo," Journal of Financial Economics, 104: 425-51.

Kregel, J.A. 2009. "Background Considerations to a Regulation of the U.S. Financial System: Third Time a Charm? Or Strike Three?" Levy Economics Institute of Bard College, Working Paper No. 557 (March).

2010. "No Going Back: Why we Cannot Restore Glass-Steagall's Separation of Banking and Finance," Levy Economics Institute of Bard College, Public Policy Brief No. 107. 
2012. "Regulating the Financial System in a Minskyan Perspective," Remarks prepared for the conference "Financial Stability and Growth," Phase 3 of the Ford Foundation project: "Growth with Financial Stability and New Developmentalism," organized by the Centre for Structuralist Development Macroeconomics of the São Paulo School of Economics of Getulio Vargas Foundation, São Paulo, Brazil. March 22-23.

2013. "Lessons from the Cypriot Deposit Haircut for EU Deposit Insurance Schemes," Levy Economics Institute of Bard College, Policy Note. April.

McCulley, P. 2007. “General Discussion: Housing and Monetary Policy,” in Housing, Housing Finance and Monetary Policy. Proceedings of a symposium sponsored by the Federal reserve Bank of Kansas city, Jackson Hole, Wyoming.

Mehrling, P. 2010. The New Lombard Street: How the Fed Became the Dealer of Last Resort. Princeton, NJ: Princeton University Press.

Mehrling, P., Z. Pozsar, J. Sweene, and D. Neilson. 2012. "Bagehot was a Shadow Banker: Shadow Banking, Central Banking and the Future of Global Finance," August. Available at: http://papers.ssrn.com/sol3/papers.cfm?abstract_id=2232016

Minsky, H.P. 1988. "Money Manager Capitalism, Fiscal Independence and International Monetary Reconstruction," paper prepared for a Round Table Conference, "The Relationship Between International Economic Activity and International Monetary Reconstruction.” Castle Szirak, Hungary. August 25-26.

1991. "The Rationale for the Conference: An Agenda for the Good Financial Economy, Remarks Prepared for Conference "Restructuring the Financial Structure for Economic Growth," Levy Economics Institute of Bard College

1992. "Stabilizing an Unstable Economy: Testing the Institutional Structure," paper prepared for a session on June 16. The Hyman P. Minsky Collection at The Levy Economics Institute of Bard College. Photocopy.

1994. "Financial Instability and the Decline (?) of Banking: Public Policy Implications," Levy Economics Institute of Bard College. Working Paper No. 127 (October).

2008. Stabilizing an Unstable Economy. New York, NY: McGraw Hill.

Moe, T.G. 2012. "Shadow Banking and the Limits of Central Bank Liquidity Support: How to Achieve a Better Balance Between Global and Official Liquidity," Levy Economics Institute of Bard College, Working Paper No. 712. April.

Nersisyan, Y. 2013. "Multifunctional Banking and Financial Fragility: What should Banks do?" Ph.D. diss., University of Missouri-Kansas City.

Omarova, S.T. 2011. "From Gramm-Leach Bliley to Dodd-Frank: The Unfulfilled Promise of Section 23A of the Federal Reserve Act," North Carolina Law Review 89: 1683-1769. 
Pozsar, Z., T. Adrian, A. Aschraft, and H. Boesky. 2010. "Shadow Banking," Staff Report No. 458, Federal Reserve Bank of New York.

2013. "Shadow Banking," FRBNY Economic Policy Review. December.

Pozsar, Z. and M. Singh. 2011. "The Nonbank-Bank Nexus and the Shadow Banking System," IMF Working Paper WP/11/289

Pozsar, Z. 2011. "Institutional Cash Pools and the Triffin Dilemma of the U.S. Banking System," IMF Working Paper 11/190

Shull, B. 2002. "Banking, Commerce and Competition under the Gramm-Leach-Bliley Act," Antitrust Bulletin 47, no 1 (Spring): 25-61.

2012. "The Impact of Financial Reform on Federal Reserve Autonomy,” Levy Economics Institute of Bard College, Working Paper No. 735. November.

Wilmarth, A.E. Jr. 2009. "The Dark Side of Universal Banking: Financial Conglomerates and the Origins of the Subprime Financial Crisis," Connecticut Law Review. Vol. 41, No. 4 (May).

Wray, L.R. 2010. "What do Banks do? What should Banks do?” Levy Economics Institute of Bard College. Working Paper No. 612 (August).

Wray, L.R. 2012. "Improving Governance of the Government Safety Net in a Financial Crisis," Ford Foundation project, "A Research And Policy Dialogue Project On Improving Governance Of The Government Safety Net In Financial Crisis." 